\title{
Shameless, the push-pull of transatlantic fiction format adaptation, and star casting
}

Article

Accepted Version

Knox, S. (2018) Shameless, the push-pull of transatlantic fiction format adaptation, and star casting. New Review of Film and Television Studies, 16 (3). pp. 295-323. ISSN 1740-7923 doi: https://doi.org/10.1080/17400309.2018.1487130 Available at https://centaur.reading.ac.uk/71997/

It is advisable to refer to the publisher's version if you intend to cite from the work. See Guidance on citing.

To link to this article DOI: http://dx.doi.org/10.1080/17400309.2018.1487130

Publisher: Taylor \& Francis

All outputs in CentAUR are protected by Intellectual Property Rights law, including copyright law. Copyright and IPR is retained by the creators or other copyright holders. Terms and conditions for use of this material are defined in the End User Agreement.

\section{www.reading.ac.uk/centaur}

\section{CentAUR}

Central Archive at the University of Reading

Reading's research outputs online 


\section{Shameless, the Push-Pull of Transatlantic Fiction Format Adaptation, and Star Casting \\ Simone Knox, University of Reading}

With a long history of transatlantic exchanges, recent years have seen a notable number of UK-to-USA format adaptations. Factually-based programming (including the Idol franchise) has generally been the most numerous, the most commercially successful and received the most sustained critical attention (e.g. Oren and Shahaf 2012). However, adaptations of fiction formats have met with increasing scholarly attention, and this article will build on this work, interested in the ways in which, as Jean K. Chalaby has noted, the adaptation process for scripted formats: cannot be as perfunctory as for other genres. Scripted genres are the most culturally sensitive, and a comedy or drama cannot be reproduced as mechanistically as a game show or talent competition. [...] Any scripted adaptation must go beyond copycat television and reactualize the script for a new audience. $(2016,6)$

This article will explore the complex push-pull of factors involved in adapting fiction formats across the Atlantic. Here, my invocation of the term 'push-pull' differs from Annette Hill's recent usage in her discussion of fiction format adaptation, where 'the idea of push-pull dynamics is understood as complicated power relations in the transactions between television industries and audiences.' (Hill 2016, 755) Instead, I draw on Albert Moran's $(2009,88)$ identification of a push-pull tendency in the television format trade between the poles of homogeneity/convergence and heterogeneity/difference. While Moran's analysis is specifically focused on the issue of language, his attention to the conflicting impetuses that mark formats can be usefully linked to Heidi Keinonen's (2016) emphasis on format adaptations as complex sites of cultural - and, I would add, industrial - negotiation.

Keinonen furthermore locates a schism within existing format scholarship, distinguishing between broader analyses of global format trade (which draw on a political economy approach and frequently do not pay sufficient attention to cultural issues) and analyses of individual case studies, which 'usually limit themselves to the analysis of the final product, the television text, thus ignoring other levels of format industry, like production and reception.' $(2016,4)$ In my endeavour to undertake an analysis of a specific transatlantic format adaptation that engages with both cultural and production/industry contexts, I have found the term 'push-pull' a useful idea through which to understand and articulate the tensions and negotiations that emerge in the transatlantic trajectory under investigation.

The complexity of the push-pull dynamics of interest to this article is only accentuated through the discursive scrutiny bestowed upon such transatlantic adaptations by audiences and press/critics. Fiction format adaptations are often and increasingly consumed with the source programmes as a point of reference and comparison. In the case of transatlantic format adaptations, the shared language, history and cultural commonalities between the USA and the UK only facilitate such comparative scrutiny. Furthermore, common ascriptions of cultural worth and status to the 'original' - originality here usually conflated with intrinsic merit - stack the cards in favour of the source material. Such evaluative hierarchies represent a particularly pertinent issue for UK-to-USA adaptations, as these are discursively 
caught up in long-standing US beliefs in British cultural superiority and the history of British drama programming's invocation in Anglophiliac elitism, whereby such programming serves US elite demographics as part of their discourses of distinction (Miller 2000).

The acclaim traditionally bestowed upon British actors has served to reinforce such evaluative discourses; and the final part of my analysis will pay attention to the casting of actors in fiction format adaptations in some detail. Drawing on seminal work by Richard Dyer (1992 and 1998), my discussion will make a contribution to wider debates about television and stardom, where the traditional understanding of stars as a cinematic phenomenon (see Ellis 1982$)^{1}$ has been debated by scholars such as Deborah Jermyn (2006), whose work on Sarah Jessica Parker has shown how the notion of stardom can be usefully applied to the small(er) screen. Responding to Keinonen's observation that, as a still emerging field, 'format study [...] necessitates theoretical and methodological cultivation' $(2016,2)$, my analysis will build on Christopher Hogg's (2013) work to consider star casting and star presence as a factor in the push-pull of fiction format adaptation, thus offering an important inflection (if not intervention) to debates about such adaptations.

\section{$\underline{\text { A Transitional Moment for Transatlantic Fiction Format Adaptation }}$}

The already noted evaluative hierarchies marking audience and press/critic discourses on fiction format adaptations are made more pressing in the contemporary period due to the increasing global viewer media literacy facilitated by social network media, streaming services such as Netflix, and transmedia practices. Concerning the impact of viewer awareness on UK-to-USA translations, Hogg has argued that in the context of growing media globalisation and convergence, viewers on either side of the Atlantic are increasingly conscious of a programme's status as a translation and aware of the existence of both the translation and the source material. Such transatlantic televisual knowledge and exposure, he notes, is 'significantly increased for the average viewer [...]. Such knowledge and exposure can result $[\ldots]$ in the negative critical appraisal of such translations as unnecessary, inherently inferior copies or "rip-offs"' (Hogg 2013, 117).

The complexity of the push-pull of factors involved in transatlantic fiction format adaptations is further marked by the fact that, as much as the appeal of fiction formats for US producers concerns risk management via source material that is concept-tested elsewhere, such adaptation 'does not follow a single prescribed path, nor are there systematic criteria for what comprises success or failure in this process' (Lavigne and Marcovitch 2011, xii). US television's use of British material is necessarily ad-hoc and opportunistic, dependent on the historically contingent needs, desires and assumptions of the US television industry. While the US market is easily conceived of as the dominant global exporter notoriously resistant to foreign influences, it has a long history of being open to such influences, willing and able to soften its borders, especially at times of transition.

This article explores the push-pull of factors involved in transatlantic fiction format adaptations at a time of transition through close analysis of a specific case study. The most conspicuous successes of such adaptations thus far would be Queer as Folk (C4 1999-2000; Showtime 2000-2005), The Office (BBC2/BBC1 2001-2003; 
NBC 2005-2013) and Shameless (C4 2004-2013; Showtime 2011-present), with the first two adaptations considerably outstripping their British progenitors in terms of overall longevity. There is a good amount of scholarship on these two (e.g. Barlaam 2011, Griffin 2008) and on the British version of Shameless (hereafter referred to as Shameless $U K)$. However, with the notable exception of (brief) attention by Elke Weissmann (2012) and Beth Johnson (2013), the US version of Shameless (hereafter Shameless USA) has received rather little scholarly analysis.

Interestingly, Shameless USA has received more attention by critics and within newspaper/television industry publications, in both the UK and USA. This is partly because it was launched within a flurry of transatlantic television exchange. Noticing this burst of activity, John Plunkett in The Guardian thought that the BritishAmerican co-production Episodes (BBC2/Showtime 2011-2017):

could not have been more impeccably timed. The Matt LeBlanc comedy [...] coincided with US adaptations of three of the most acclaimed UK dramas of recent years - Shameless, which launched on pay cable network Showtime last week, Skins and Being Human, which both make their Stateside debuts tonight. $(2011,3)$

In fact, Shameless USA and the meta-reflection on transatlantic adaptations that is Episodes premiered on Showtime on the very same day (9 January 2011). This was closely followed by the broadcast of the US versions of Skins (MTV 2011) and Being Human (Syfy 2011-2014) just over a week later (both on 17 January 2011), as well as the July broadcast of the transatlantic co-production Torchwood: Miracle Day (BBC1/Starz 2011). This intense flurry of transatlantic activity quite understandably caught press attention, with The New York Times' Alessandra Stanley further noting the arrival of British import Downton Abbey (ITV1 2010-2015) on PBS, feeling compelled to refer to a 'Britishification of American television.' (2011, C.1) Stanley's claim is, of course, somewhat hyperbolic. As always, the fluctuating fortunes of programming originating from Britain would see some US successes (Downton Abbey, Shameless USA), and some failures. The US version of Skins was not renewed by MTV for a second season - exactly the same fate that would befall the US version of The Inbetweeners (MTV 2012) - and Torchwood: Miracle Day so far remains the fourth and final season of Torchwood. Nevertheless, these debates have rightly positioned this transatlantic flurry within the particular historical context of the development of US television, specifically its cable market.

For example, Plunkett has noted US cable's increased scope and concomitant drive for distinction by each channel, quoting Touchpaper TV managing director (and executive producer on the UK and US version of Being Human) Rob Pursey's impression that US 'cable channels have a strong sense of who their audience is and they are looking for something which is a bit outside the mould and will set their station apart.' $(2011,3)$ This echoes the argument made by Jeanette Steemers that in the 1990s, US versions of British programmes 'were used as a means of rejuvenating American schedules in a more competitive multi-channel environment.' $(2004,105)$ Plunkett rightly highlights the significance of niche broadcasters within the USA and the UK for US cable's drive for distinction: insisting that it 'is no coincidence that all of the recent UK/US adaptations, including Skins on MTV and Being Human for Syfy, have been outside of the five main US networks' (2011, 3), he again references Rob Pursey to draw attention to the fact that the programmes getting remade as part of 
this flurry were made for the smaller British channels Channel 4 (Shameless), E4 (Skins) and BBC3 (Being Human).

It is worth considering this willingness by US cable channels to take on this edgier material in relation to a transitional moment within contemporary television, which concerns the move into original programming by streaming services such as Netflix, Hulu and Amazon Prime Video. Mareike Jenner has explored the significance of Netflix's shift towards original programming, noting a similarity in Netflix's approach to 'HBO's example of creating a brand identity where 'quality' content helps construct the brand' $(2016,263)$. This broader move - widely speculated upon and anticipated within the industry - was actualised during the early 2010s, with Netflix's announcement in March 2011 that it had commissioned House of Cards (Netflix 2013-present) an important milestone. That this would be an adaptation - of the 1989 novel by Michael Dobbs and the 1990 BBC short serial of the same name is not surprising, given that the concept-tested difference and cultural capital offered by British programming had already proved attractive to cable television's earlier drive for distinction and maturity. Given that new forms of distribution such as Netflix are understood as enabling new kinds of politics of representation (Click and Miller 2013), and that cable television's drive for distinction is increasingly competing with that by streaming services, it is not difficult to conceive of the latter's much-anticipated move as having an impact on US cable that would include its approach to format adaptation, and of the 2011 flurry of transatlantic exchange as implicated in this.

\section{Push-Pull: The Protracted Pre-Production Process for Shameless USA}

The adaptation of Shameless makes an interesting case study, both because little scholarly attention has been paid to it so far and because it is located within a transitional moment in the development of US (cable) television. Moreover, bearing in mind the already noted need identified by Keinonen $(2016,4)$ for programmespecific research on format adaptations that pays attention to not just the final product but also to relevant processes of production, Shameless USA also offers an opportunity to vividly capture the texture of the push-pull of factors that help to bring a fiction format adaptation into being (or not) and to become a critical and/or commercial success (or failure). Since its premiere, Shameless USA has achieved significant success for premium cable channel Showtime. Scoring Showtime's highest-rated drama debut in seven years (Hibberd 2011), Shameless USA's first season averaged close to four million weekly viewers across multiple platforms, making it the channel's third highest-rated programme. Remarkably, Shameless USA has managed to actually grow its initial audience across subsequent seasons (O'Connell 2014). Critical responses have included numerous award nominations and some wins, such as a 2015 Screen Actors Guild Award for lead actor William H. Macy. Showtime president David Nevins has called the programme one of the channel's 'signature series' (cited in Abrams 2015), one that has been crucial to Showtime's brand, especially after the cessation of the record-breaking Dexter (20062013).

Despite this, however, Shameless was a far from straightforwardly obvious choice for adapting, and it took years of negotiations with several broadcasters (including NBC and HBO) as well as the combined efforts of Shameless UK creator 
and executive producer Paul Abbott and high-profile US writer, producer and showrunner John Wells to get the adaptation realised. (This interestingly echoes the struggles experienced by Paul Abbott when trying to get the British version made in the UK, on which I will reflect shortly.) There are several push-pull reasons why this was such a lengthy process.

Shameless USA did not exactly follow the pattern identified by Hogg, that 'US-based translations are often the result of co-production relationships between US companies and the UK companies involved in producing the preceding British-based versions' $(2013,125)$. Neither Shameless UK nor Shameless USA are international coproductions in the sense that Shameless $U K$ is solely produced by British independent Company Pictures; and neither Company Pictures nor Abbott's own company AbbottVision are among the production companies credited for the US version. However, Shameless USA is a collaborative transatlantic endeavour in that Abbott serves as an executive producer and has spoken of his involvement: 'Every six weeks I go over to LA to work on it and in the meantime they load the rushes on to the web for me.' (cited in Wylie 2010, 5) In contrast to the more straightforward development of, for example, the US version of Life on Mars, which was co-produced by the British version's production company Kudos Film and Television (which, Weissmann notes, 'developed Life on Mars also with an eye on the US market' $(2012,85))$ and premiered only two years after the BBC antecedent, the US version of Shameless was born of a more complex, protracted pre-production history.

With Abbott's much discussed autobiographical influences behind Shameless $U K$ and his struggle to get it made in Britain - Abbott has commented that he 'had to fight tooth and nail [to get Shameless commissioned] because it's not the kind of telly that other people were used to. There's a lack of real life in TV drama.' (cited in Jeffries 2005, 6) - Shameless UK has been strongly located within a British television production context (one marked by increasing deregulation and commercial pressures). It is likely that considerations concerning exporting to and/or adapting for the USA were not paramount during its conception and development. Importantly, its subject matter (a poor dysfunctional family, headed by a feckless, drug-taking father, living on a council estate in Manchester) is deeply implicated in issues concerning social class in a Northern English context. This connects Shameless UK to British television's long traditions of social realist drama and Northern Realist drama (see Millington 1993); and Robin Nelson has insisted that Shameless UK is 'distinctively British' $(2007,52)$ in the way in which it draws on social realism as well as on popular television forms of soap opera and sitcom.

The already mentioned cultural commonalities between the USA and UK notwithstanding, this particular British lineage does not readily offer lines of congruence and resonance for US television production. As Weissmann points out, this type of British drama has not been an easy bedfellow for US television, with highly acclaimed dramas such as Boys from the Blackstuff (BBC2 1982) problematically presenting 'an exact opposite to the spectacle of wealth that allowed (US and non-US) viewers to escape their own troubles' $(2012,60)$. With reference to programming including short drama serial Our Friends in the North (BBC2 1996), Weissmann further argues that 'the history of Northern Realist drama in the USA indicates more generally that US broadcasters were conservative in their estimation of what audiences wanted to see in terms of UK productions or their adaptations.' (ibid., 
emphasis added) Certainly, the question posited by HBO executive Mike Lombardo at the time of the HBO Shameless development deal, 'how do you move that show to America and not lose its essence?' (cited in 'HBO preps' 2008/09, 8), proved a challenge, one that this renowned premium cable channel would not go on to resolve.

In a push-pull movement, what needs to be set vis-à-vis these components impeding the likelihood of an adaptation of Shameless $U K$ for US television, are factors facilitating this transatlantic fiction format adaptation. These are factors that concern both the British progenitor and the specific localisation choices made for the Showtime version. That it was not a more conventional co-production notwithstanding, Shameless USA could draw on 'the active role of UK gatekeepers in the USA' (Weissmann 2012, 62), with a sustained investment of time and energy on the part of Paul Abbott. He has repeatedly praised US television; and his preferred working methods, especially working as part of collaborative teams to create long seasons, are quite compatible with those long-established in US production. (As a result, the fact that Shameless $U K$ 's premise is suitable for a long run in a way that is not common for British drama may have helped to make it easier to adapt in the USA. Of course, that it had been renewed for a number of seasons by the time of the Showtime development deal would have been helpfully reassuring.)

But crucially, the US adaptation also benefitted from and depended on the driving force of John Wells, whose television track record includes the highly acclaimed dramas China Beach (ABC 1988-1991), ER (NBC 1994-2009), The West Wing (NBC 1999-2006) and Southland (NBC/TNT 2009-2013). That Abbott and Wells would soon collaborate on the project is indicative of an increasing transatlantic industry emphasis on awareness of production developments and developing professional contacts and networks. Wayne Garvie, then managing director of international production at All3Media, has described this increasing production transnationalisation as follows: 'There is not an American agent or broadcasting executive who does not know what is working and what's not working in the UK, and every British producer worth their salt has an ongoing relationship with American agents and the studios.' (cited in Plunkett 2011, 3)

Moreover, even though Shameless $U K$ was not created with an eye firmly on the US market, once it proved a success on Channel 4, it is not surprising that efforts were made to tap into the opportunities for revenue generation and international market exposure that US television holds for exporting and/or format adaptation. Here, attention needs to be paid to the fact that Shameless $U K$ is distributed and Company Pictures is owned by the aforementioned All3Media. All3Media is one of the 'super-indies' discussed by Chalaby (2010). It is a production company that benefitted from the 2003 UK Communications Act, which shifted ownership of programme rights to independent producers, and was able to consolidate by acquiring a range of companies, including Company Pictures. As such a super-indie, All3Media places emphasis on operating transnationally, and Shameless $U K$ was exported to several countries, including Australia, France and the USA (BBC America and the Sundance Channel). This limited release of the British version on US television can be understood as helping to place the programme 'on the radar' for US executives without risking over-exposure of the format. 
Certainly, that it would be on cable that a US version of Shameless would materialise is unsurprising, not least given the explicit content. Abbott's following comments from late 2005, the time of the deal with NBC - the network had at that point been scoring improving critical and commercial success with the US version of (the much less explicit) The Office - are quite telling here:

there are restrictions left, right and centre. [...] And they get in a complete state about anything to do with sex - remember the furore about Janet Jackson's nipple? I predict the anal sex in episode two might be a bit of a problem! (cited in Rampton 2009)

In addition, as Weissmann (2012, 61-62) points out, programming linked to the UK has fared better in US television when it has fitted available frames of reference, citing the development of similar dramas like The Wire (HBO 2002-2008) as significant to the success of Shameless USA. I would like to flesh this point out by adding that, indeed, cable in recent years has shown a willingness to commission grittier programmes that have moved beyond the usual spectacle of wealth towards the representation of working class environments, such as The Wire, Rescue Me (FX 2004-2011), and Nurse Jackie (Showtime 2009-2015). What is more, Showtime's earlier success with its version of another edgy, risky British drama, namely Queer as Folk, served as an additional frame of reference that would work in the favour of the Shameless Showtime development deal. As the ultimately unsuccessful deals with NBC and HBO remind us, whilst such precedents and frames of references are undoubtedly reassuring to executives, they are in themselves no guarantee for success; it is a historically contingent, if not precarious, constellation of favourable factors that determines whether an adaptation gets commissioned and becomes successful or not.

\section{The Politics of Representation: Genre, Humour and Style}

With Shameless, a further, crucial favourable component concerns the fact that, as a number of scholars have pointed out, as much as Shameless $U K$ is connected to a British social realist tradition, its social critique is also, at least to some extent, rendered safely palatable, via its deployment of genre, humour and style. Stephen Baker (2009) has noted that the programme's politics of representation are marked by the absence of a challenge to or explanation of the marginality of the working class Gallagher family. Aspects of genre (including comedy and soap) are utilised in such a way that class is portrayed as a 'lifestyle' and the 'experience of the post-industrial poor in Shameless is seen as discrete from the structural causes of unemployment and deprivation.' (Baker 2009, 452)

Baker further argues that, helped by the potential of genre to function as a site of symbolic struggle, the drama nevertheless does work to recuperate and 'reincorporate its working-class characters within a national imagery' (ibid., 455) from which the working class poor have become detached. Not dissimilarly, Nelson has reflected that:

If Paul Abbot's [sic] aim had been to expose the plight of 'sink' estates in contemporary Britain and to invite action to remedy their ills, the series would indeed be placed in such a [British social realist] tradition. But [...] the sitcom dimension of Shameless primarily invites laughter rather than sympathy or concern. $(2007,50)$ 
Nelson's discussion concludes that the choice to be an open and playful text that floats political questions and disturbs viewers into active engagement 'may be more politically effective for the twenty-first century' (ibid., 51). However, his thoughts about the function of humour link to political author Owen Jones' strong concern that the 'danger with [Shameless $U K$ ] is that the viewer is encouraged to laugh at, rather than understand, the lives of the characters.' $(2011,130)$

The programme's use of form and its stylised aesthetics have come under especial scrutiny in terms of these problematic politics of representation. Shameless $U K$ 's fusion of realism with elements of surrealism and expressionism (including whip pans, excessive sound effects and freeze frames) and use of a colourful, vibrant mise-en-scène have been understood by Baker as helping to oppose working class authenticity and exuberance with the sterility of the middle class. In this way, Baker argues, 'Shameless makes working-class environments stand for something more than the 'social exclusion' and deprivation that its opening sequence might suggest.'

$(2009,461)$ Johnson has maintained that the programme, in fact, operates to situate and then intelligently undermine generic representations of social realism, characterised by an emphasis on the real difficulties and drabness of working-class life. Instead, Abbott invokes and evokes [...] an exuberance in the everyday coupled with a fierce lack of shame in order to demonstrate the determination of the Gallagher family to remain together. $(2013,4)$

Here, her work has resonance with that of Glen Creeber, which has taken issue with some of the ideological underpinnings of social realist drama. As Creeber has argued:

By taking the vibrant aesthetics of contemporary social realism to its limits (particularly its introduction of self-referential techniques), Shameless is able to implicitly highlight and foreground the subjective nature of its narrative construction. This, in turn, inevitably challenges the claims of authenticity and ethical superiority commonly ascribed by the conventional codes of social realism that placed so much of its own textual authority on its ability to create an authentic 'slice of life'. (2009, 432-433)

What can be gleaned from the existing scholarship on Shameless $U K$ is that there is an inherent ambivalence in the programme's politics of representation: one that distinguishes it from past Northern Realist programmes such as Boys from the Blackstuff; one that is underestimated in discourses by US critics such as Matt Zoller Seitz, who in an article for Salon argued that Shameless USA 'remakes a hit British comedy - but leaves its provocative social critique behind' (2011); and one that through its very ambivalence can be suitably activated and inflected according to an adaptation's contexts, needs and preferences. As Weissmann argues, these ambivalent politics of representation of Shameless $U K$ have especial significance for transatlantic adaptations:

Importantly, Shameless similarly avoids these issues [i.e. industrial relations and working class politics], emphasizing instead personal failure and individual choice over class relations, and thus perhaps being less risky to broadcasters in a country where being connected to socialist or communist politics has in the past meant exclusion from the political and - just as often cultural sphere of influence. $(2012,62)$ 
Certainly, it is useful for the purposes of exporting and adapting Shameless $U K$ that the choice was made to not highlight drabness and the ways in which it continues to shape the life of the poor even in the present day. To do so would be certainly be a worthwhile and indeed radical act; one that is unlikely to materialise within contemporary British television drama, which has to contend with intense deregulatory pressures to be commercially viable. British television has long ceased to be the haven for gritty social realist drama that it has equally long been assumed to be and with which is still associated (especially by critics elsewhere). This is reflected in the fact that Paul Abbott, who had already been aware of the limited opportunities for getting social realist drama commissioned when developing Clocking Off (BBC1 2000-2003), had to, as already mentioned, 'fight tooth and nail' (cited in Jeffries $2005,6)$ to get Shameless UK commissioned. This was despite his growing track record of both critical and commercial successes, including his work for Coronation Street (ITV1 1960-present), Cracker (ITV1 1993-2006) and Clocking Off.

Not only that, but it also took years, a redevelopment of idea, genre and tone, as well as a change of narrative form for Shameless $U K$ to materialise. George Faber, the co-founder of Company Pictures, recalls that he was BBC head of single drama in the 1990s when Abbott first approached him:

It was substantially autobiographical, and [Abbott] wanted to write it as a single film for television. He wrote about half of it. The tone was very downbeat and grim and he said, 'This isn't right, is it'? [...] [Several years later Abbott] was able to return to that period of his life and view it through a comedic prism. (cited in Wylie 2010, 5)

With the heyday of the single play certainly long gone by the 1990s, it is not difficult to see that Shameless $U K$ needed to be made substantially different from its initial conception to be suitable for its present circumstances of British television drama production. And, while I have argued that Shameless $U K$ was not created with an eye firmly on the US market, those circumstances meant that the way in which Shameless $U K$ was reconfigured (i.e. to be more mainstream-friendly and less gritty) would help not only its commissioning for British television, but also aid its exportability to and adaptability for US television within an increasingly globalised television production landscape. Coming back to the issue of style, the success of Shameless UK in terms of its British broadcast, US exportation and adaptation can also be thought of in relation to the fact that, as Abbott himself has acknowledged in relation to his own projects (Cooke 2015, 200-201), British television drama of recent years has been strongly influenced by the aesthetics of US television drama, against which it competes on its home turf and internationally. To some extent, distinctions between British and US television have become porous (if not inapplicable) at the level of conception and commissioning, as converging pressures face potential projects in each market, situated within an overarching transnational framework of neoliberalism.

The Politics of Representation: The Family, Social Structures and Social Class

Having mapped the factors concerning the British progenitor that facilitated the transatlantic adaptation of Shameless, I will now move my discussion to the localisation choices made for Shameless USA, and the way in which the transatlantic adaptation process has responded to and negotiated the format established by Shameless UK. Notwithstanding that, as has been noted, ${ }^{2}$ the Showtime drama especially in its early stages adhered rather closely to the British version, important 
changes were made and British socio-cultural references substituted to address cultural proximity (Straubhaar 2000). Johnson encapsulates this particular push-pull well when she notes that: 'Set in the southside Chicago projects rather than the outskirts of Manchester, and focusing on a family that is more working-class than underclass, the Gallaghers are represented as the same, but different.' $(2013,129$; emphasis added) ${ }^{3}$ With a bigger house for the Gallagher family (which is in keeping with the conventions of US television production), the inclusion of actors of AfricanAmerican ancestry into the core cast and the exchange of various references (e.g. 'blow job' is exchanged for 'hummer' (Johnson 2013, 130)), the programme is made more immediately recognisable and relevant to US viewers.

The noted Britishness embedded within the format could also be negotiated via the universal narrative theme of family. A long-serving ideological stalwart of much television drama, the notion of the family has certainly been stressed within the extra-textual and promotional discourses surrounding Shameless USA. John Wells has commented that his initial attraction to the project was centred on the familial love and community in an age of increasing social isolation:

$[\ldots]$ I found myself very attracted to the family and the way in which these kids were raising themselves and cared for each other and looked out for each other so then you add all the humor... I think there's a love for each other that I find very seductive. (cited in Halterman 2012)

When asked for the start of the fifth season what he credits for the show's longevity, William H. Macy echoed Wells' sentiment:

It's a beautifully conceived family, and that makes it universal. There are archetypes in it, but it's a new, fresh look at these archetypes - and at the base of everything, they love each other, and they help each other. It's all about family. Family's thicker than anything. (cited in Anderson 2015)

Wells and Macy are certainly correct in asserting the importance of family to the Shameless format: broader social changes concerning and old-fashioned representations of the family are being worked through in that the conventional nuclear unit here has given way to a 'troubled or fractured' (Taylor 1989, 65), extended - and in the US version, cross-ethnic - family. Here, the father is most certainly not the customary patriarchal bread-winner devotedly supported by the stayat-home mother. Nevertheless, the centrality of the family is quite conventionally reaffirmed within both Shameless UK and Shameless USA, with the pilot of both versions ending with the family cheerfully gathering around the kitchen table (albeit that the mother remains absent and the father's participation is limited to being passed out on the floor). Shameless USA extends the British version's assertion of the surviving, functioning family and stresses familial love: as Johnson $(2013,129-130)$ has observed, the US Gallaghers have warmer relationships with one another; and there is emphasis on their group dynamic as a relatively well-oiled machine (e.g. the children gather around the kitchen table at the beginning of the pilot episode as well, attending to several tasks together).

What both versions - as well as Wells and Macy, whose comments side-line the dysfunctionality of the Gallaghers, especially of the parents - thereby express is ideologically arguably quite regressive. After all, the family needs to be understood not only as a site where dominant social values and identities are re-affirmed, but also as an ideological construct itself (Flax 1982), but there is little to no recognition of the 
latter to be found here. By upholding the centrality of the family as a fundamentally positive idea and affirming the myth of redeeming familial love, the politics of representation of Shameless UK and especially Shameless USA promote a sense of stability and reassurance that do not work to question dominant power relations, societal order and consensus ideology, but instead off-set some of the more difficult, grittier aspects of the format.

With its positive focus on the social unit of the family comes Shameless USA's concomitant turning away of attention to wider social structures. ${ }^{4}$ The programme has been singled out for criticism in relation to this within US press discourses. As Zoller Seitz elaborated in 2011:

[...] the show conspicuously avoids any mention of government help welfare, food stamps, Social Security payouts, anything. Why? Maybe it's because Abbott and Wells couldn't devise a suitable U.S. equivalent for the English/Irish/Scots fiction tradition of the alkie father who drinks away the dole money. Or maybe it's due to a knee-jerk belief on the part of American film and TV producers that any character on public assistance will be seen as unsympathetic, perhaps innately worthless. (2011)

With the state and wider social structures thus marginalised, Shameless USA locates failure on the level of the individual, which chimes with American Dream discourses. This particular ideological displacing of attention is encapsulated in comments made by Showtime president Nevins, who has insisted that Shameless USA is 'less about the working class nature of the show and more about how it stares alcoholism in the face.' (cited in Rochlin 2011, AR.7) By focusing on the effects of Frank Gallagher's alcohol abuse, which in season four of the US version leads to liver failure, Shameless USA does not seek to understand this individual 'choice' as closely embedded in wider social contexts that produce inequality and facilitate working class substance abuse. This is captured in episode 'Lazarus' (4.12), in which Macy's Frank has his first drink after his liver transplant. Placed in a wintery landscape, he is framed by Chicago skyscrapers in the background and most certainly not depicted within the kind of working class squalor and drab hopelessness that facilitate if not engender working class substance abuse. Screaming the words 'Is that all you got? You see me standing here? You lost, asshole! I'm alive, motherfucker!' across Lake Michigan at an unseen deity, with his back turned to the social order represented by the buildings, his failing is here distinctly linked to his personal struggle with faith and the meaning of life. In this way, Shameless USA picks up on an ideological tendency already present within the British version - as Baker has noted, in Shameless UK, 'Frank Gallagher's unemployment appears a mere character trait, attributable to his general idleness' $(2009,463)$ - and heightens it to suit its particular ideological project.

With so much ideological criticism that can (and should) be levelled at the US version, it is fair to point out that Shameless USA still moves its politics of representation outside of the usual parameter of much US television drama: it depicts the working class, which is unusual enough in itself given the aspirational inclination of much US fictional programming in general and high-end drama in particular. As part of their study of US television, Sut Jhally and Justin Lewis have argued that: In the TV world, normality is attached to being comfortably middle class, being average means being above average. To be outside this world is, by 
implication, to be out of the mainstream, marginal, and, in a socioeconomic sense, conspicuously unsuccessful. $(1992,74)$

Shameless USA is certainly located outside the world of the comfortably middle class and the mainstream, and it has been aided in this by economic struggles becoming topical headline news during the post-2008 global recession. Although transatlantically reconfigured from the underclass to the working class, as Abbott has insisted (with comparative reference to US network sitcoms), it is 'not 'My Name is Earl' or 'Roseanne.' It's got a much graver level of poverty attached to it. It's not blue collar; it's no collar.' (cited in Rochlin 2011, AR.7) Not only does Shameless USA depict US economic deprivation, it has also importantly resisted placing this deprivation within the most stereotypically associated contexts. As Wells has reflected:

When we first started pitching, everybody kept gravitating towards the South or putting it in a trailer park, and I kept saying, 'Well, no,'[.] We have a comedic tradition of making fun of the people in those worlds. The reality is that these people aren't 'the other' - they're people who live four blocks down from you and two blocks over. (cited in ibid.)

In this way, the US version of Shameless engages with and presents a different slice of American socio-cultural life. This is crucial given that past debates of global television flows have built their concerns regarding the dominance of American media on the basis of a presupposed American homogeneity, which seeks to remake the rest of the globe in its homogenous likeness. Hogg has rightly taken issue with this, commenting that this 'oversimplifies rich spectra of cultural taste and disposition through processes of homogenisation, by presupposing instead the existence of a uniform "all-American" or "indigenous" national culture.' $(2013,122)$ While it is undoubtedly the case that US media exports tend to focus on 'the socio-cultural middle-ground' (ibid., 120), it has been the big transatlantic fiction format adaptation successes of recent years, namely the US versions of The Office and Shameless, that have emphatically challenged notions of American homogeneity and, through their depictions of (relative) mundanity and poverty, have shown US culture to be richer than has long been assumed.

\section{Opening up the Contested Cultural Space of Format Adaptations: Star Casting}

For the final part of my discussion, I now turn to a factor in the push-pull of fiction format adaptation to which insufficient attention has thus far been paid within the existing scholarship on format adaptations: namely the casting and presence of a star performer. Whilst Shameless USA followed the British progenitor quite closely in its early stages, I want to draw attention to the ways in which, even within the pilot, Shameless USA is significantly repositioned from Shameless $U K$ because of the presence of William H. Macy. My argument here is that the industrial strategy of star casting can help to open up the contested cultural space that Hogg has insightfully discussed in relation to format adaptations. As Hogg puts it,

The perceived singularity of the TV text [...] leads to an understanding of the same-medium recreation as interloper or competitor, vying to inhabit the same artistic space previously occupied solely by its textual precursor. In the case of translation, this notion of contested artistic space also constitutes contested cultural space, with the US variant [...] seen as 'rereading' the UK variant through translation and, in so doing, re-inscribing a singular artistic and 
cultural space with its own voice, its own version, and in its own image. $(2013,122)$

As part of his discussion, Hogg already considers the significance of actors and the meanings that they bring to a role/programme:

Actors carry with them to each new performance what Marion Jordan (1981, 197-8) describes as a 'background resonance': a reverberation of associations regarding their previous roles, as well as their real-life exploits and star personas. Such inter-/extra-textual associations are often consciously encouraged and incorporated in production, in order to embed different stratifications of reference and significance within the fabric of the text. These stratifications of significance can work to undermine the 'translation as erasure/re-inscription' paradigm, as they depend upon generating intertextual relationships, rather than dismantling and cannibalising intertexts, for their construction. (ibid., 127-8)

Building on Hogg's ideas, my interest lies in teasing out the ways in which star casting can help to open up contested cultural space and help fiction format adaptations gain more textual identity in their own right as well as inflect discourses of reception, both of which may be especially important in the recent transitional moment identified earlier. ${ }^{5}$ The issue of casting holds particular significance for UKto-USA adaptations, as British actors and acting are part of culturally hierarchical discourses that link back to the already mentioned Anglophile elitism. There is a long tradition in the USA of reverence for British actors based on their links to British theatre (especially Shakespeare) and British drama school training. Weissmann has noted that one reason why the US version of Life on Mars struggled was because of the perceived weakness of the acting in the US version, and some viewers at least would have been likely to be critically comparative of the acting in both versions and positively inclined towards the British version. She argues: 'Indeed, adaptations can only be fully successful if they recognize the taste hierarchies that are specific to particular audiences. UK performances are regularly judged qualitatively superior, particularly in the Anglophile discourses of the US cultural elite.' $(2012,94)$

Given this potential peril, it is here interesting to observe that recent years have seen two successful US adaptations of British dramas with central performances that have been understood as belonging to the best of British acting, namely Shameless UK's David Threlfall and House of Cards' Ian Richardson; two highly acclaimed actors with close connections to British theatre. The potential Anglophiliac peril identified above was quite possibly made more pressing for both Netflix's House of Cards and Shameless USA, as their British progenitors had been exported to the USA - the BBC's House of Cards was broadcast on PBS' Masterpiece Theatre in 1991 and Shameless UK was shown on BBC America and the Sundance Channel thus providing points of reference with the performances by Richardson and Threlfall; the latter of course more likely to be fresh in US viewers' memories. Additionally, the issue of Anglophiliac comparisons could be understood as posing a particular risk for non-network channels, whose elite demographics and critics are likely to participate in the discourses of distinction that feed into Anglophiliac bias, and for whom critical acclaim is crucial currency. 
Thus laying themselves open to potential criticism, these two successful US adaptations both feature star casting for the lead role: William H. Macy as Shameless USA's Frank Gallagher and Kevin Spacey as Netflix's House of Cards' Frank Underwood. At the time of casting, both were acclaimed high-profile US actors associated with prestigious theatre and auteur film productions: for Macy, the latter includes the career-defining Fargo (1996), Boogie Nights (1997) and Pleasantville (1998); for Spacey, Seven (1995), The Usual Suspects (1995) and American Beauty (1999). (Spacey was artistic director of the Old Vic theatre in London from 2004 to 2015, which interestingly reduces the discursive gap between him and British actors and acting.) Macy furthermore has connections to 'quality' television drama via his recurring role in medical drama $E R$ (NBC 1994-2009). Of course, the industry practice of casting well-known performers (especially those who have achieved success on the big screen) is neither new nor surprising, seeing as it can help to bestow visibility and status to productions in a crowded, if not cluttered, industrial landscape, both nationally and globally. In the context of non-network television, if such star casting raises the viewership by even only a few hundred thousand viewers, it could make a noticeable difference to a programme's ratings.

Crucially, with transatlantic adaptations, casting well-established and esteemed performers such as Macy and Spacey can help to deflect Anglophiliac criticism and positively address comparative evaluations. Their casting bestows additional textual identity to the adaptation, lessening the role of the British progenitor as the discursive point of reference: Shameless USA becomes less 'the US version of Shameless' and more 'the William H. Macy version of Shameless', just as Netflix's House of Cards becomes less 'the American House of Cards' and more 'the Kevin Spacey House of Cards'. (Of course, following the allegations of sexual assault and harassment against Spacey that started to emerge in October 2017, this will see a significant inflection for the show's sixth and final season. ${ }^{6}$ That star casting was an important component in the formative stages of the two projects is reflected in comments by House of Cards executive producer David Fincher that he waited for a year for Spacey to become available (see Sepinwall 2013). It is further confirmed by industry reports that the original deal with NBC to develop a US version of Shameless had another high-profile US actor involved, namely Woody Harrelson ('HBO preps' 2008/09, 8). This strongly suggests that star presence was always foundational for adapting Shameless for the USA. This has an interesting inverse parallel with Shameless $U K$, for which the rising stardom of one of its main cast led to his departure: James McAvoy, cast for the role of Steve which proved to be his breakthrough part, left Shameless $U K$ after the first two seasons to work on high profile feature film projects including The Last King of Scotland (2006) and the $X$ Men blockbuster franchise.

\section{Two Very Different Frank Gallaghers: David Threlfall and William H. Macy}

Having identified the significance of star casting for fiction format adaptations, a closer comparative look at the presence of Macy and Threlfall in their respective versions will be illuminating and provide useful specificity to my discussion. Both Macy and Threlfall had long careers as professional actors before Shameless, and both were acclaimed for and had achieved success with their work. After early high profile success - especially with The Life of Adventures of Nicholas Nickleby, which he played on stage and on screen (C4 1982), and for which he received Tony and Emmy 
award nominations - Threlfall's career settled into the ebb and flow more typical of a working actor, reaching a particular professional low point not long before he was cast as Frank Gallagher. With high-profile roles in US film and television, Academy Award nominee Macy, however, became internationally recognised, thus bringing a profile to Shameless USA in a way that Threlfall could and did not. Unlike Threlfall, Macy represents star casting. What adds to this distinction between the two is that Macy is much more comfortable with publicity and interviews than Threlfall. Furthermore, while neither Macy nor Threlfall have conventional leading man looks with much of the press discourse on each commenting on Macy's 'hangdog face' (Macdonald 2004, 17) and Threlfall's 'lived-in' face (Duerden 2005, 14) - Threlfall is noted for possessing a 'mutable face and image' (Elkin 2004, 23). This is a malleable look that has rendered him close to unrecognisable across different roles. Macy, on the other hand, has more distinctive, readily identifiable facial features (especially his furrowed brow); and, as I argue below, his recognisable star presence inflects and informs Shameless USA in interesting and important ways.

Another noteworthy point of difference between the two actors is that while both are acclaimed for their craft, they have quite contrasting approaches to acting. Threlfall enjoys an immersive approach that involves extensive research, such as spending days in a character's home town in preparation for a role. Having conceived the acting technique 'practical aesthetics' with his long-time collaborator David Mamet, Macy prefers to focus on the character as written on the page. As Macy has commented: 'The truth of the matter is that every single thing you need for acting is right there on the page.' (in Luckhurst and Veltman 2001, 65) This difference interestingly probematises the links that are frequently (and often reductively) made between US actors and Method styles of acting, as well as the binary contradistinction upheld between US actors and British actors; the latter conventionally understood as very text-based in their work (see Knox and Cassidy 2018 (in press)).

What this difference in the actors' approaches facilitates is that Threlfall produces a fully embodied performance of an alcoholic miscreant, with a glassy stare, slurry delivery and jerky, shaky movements. Macy's Frank Gallagher looks healthier, has crisper diction and moves with more control. This contrast is reinforced through certain choices of costuming and make-up: Threlfall wears the same scummy clothes for extended periods of on-screen time, his skin looks blotchy, his eyes are red and his hair is strikingly matted with grease. Macy's Frank looks generally cleaner, undergoing more costume changes, and his hair, although somewhat unkempt, has not grease in its roots but instead the bounce and lift that only professional blow-drying can achieve. Johnson $(2013,130)$ and Zoller Seitz (2011) have noticed the more polished appearance of the actors in the US version; it seems that greasy roots are too transgressive even for the more permissive context of premium cable television. ${ }^{7}$

Interestingly, Macy's participation in a high-end designer cover shoot for Chicago's Michigan Avenue magazine in December 2014 drew much attention by critics, who highlighted the contrast between his coutured look and his appearance as Frank Gallagher. These photographs certainly reflexively underline Macy's complex star image and presence: lacking the physique and wrinkle-free look of the models or leading men such as Ryan Reynolds one is accustomed to seeing in such designer shoots, Macy does not quite fit into the aesthetic frame in which he is placed here. However, because of his very recognisable look as the high-profile actor William $\mathrm{H}$. 
Macy, and the very fact that he appears in artful poses sporting luxury brands including Armani and Ferragamo, these photographs also remind their viewer that Macy the star does not quite fit into the role of Frank Gallagher in Shameless USA either. As a performer, his structured polysemy, that is, 'the finite multiplicity of meanings and affects' (Dyer 1998, 3) that Macy embodies, contains both an everyman quality (e.g. Dalton 2007, 17) - which, within the ideology of US screen culture, has seen him often cast as 'feckless losers' (Geary 2007, 7) - and star quality. In this way, Macy to some extent embodies Dyer's (1998) conception of the 'ordinary/extraordinary' paradox of stardom, namely that stars are constructed as simultaneously 'typical' and 'special.'

Macy's star image fits the role of Frank Gallagher in some respects (his 'everyman' and 'loser' connotations) and fits less well in other aspects (his connotations of intelligence and articulacy, his frequent casting as middle class characters); his Frank makes, as Dyer (1998, 127-129) would put it, 'selective use' of elements of Macy's polysemy. Add to this Macy's less lived-in look in Shameless $U S A$, his approach to acting the role (Macy is not an actor who seeks to absolutely elide the difference between himself and the characters he plays), and the very fact of his recognisable star presence, and Macy does not become Frank Gallagher in the way that Threlfall - who has been praised by dramatist David Edgar for his 'capacity to completely inhabit a character' (cited in Jury 2007, 38) - does. This is less intended as a criticism of Macy's performance, and more as a comment on his presence within the text, which impacts the grittier aspects of the drama and its depiction of poverty.

This is strikingly articulated in the promotional imagery used for the first season and DVD box set covers of both versions of Shameless, which have Frank Gallagher surrounded by family and close friends. Sitting on a sofa, Threlfall's Frank has a can of beer in one hand and a cigarette in the other, staring moodily ahead. There is a distinct lack of energy about him (at the time, a generally not well-known performer) in this picture, which contrasts sharply with Macy in the corresponding US material: the internationally well-known Macy is here standing on a coffee table, arms extended, hair blowing backwards, spilling his drink and smiling cheerfully at the camera/viewer, his 'worn-in frown' (Macdonald 2004, 14) temporarily absent. Vitality and dynamism clearly animate this image, which ostensibly depicts a poor, dysfunctional family headed by an alcoholic father.

Such is the construction of this promotional image that it can be usefully mapped out against Dyer's (1992) seminal discussion of 'Entertainment and Utopia', which he originally developed in the context of Hollywood musicals. This promotional image for Shameless USA remarkably encapsulates the five categories of entertainment's utopian sensibility, expressing abundance, energy and intensity, transparency and community through the characters coming together in communal celebration marked by joyful vitality and sensuous materiality. These are presented as utopian solutions to the scarcity (poverty, unequal distribution of wealth), exhaustion (work as a grind, pressures of urban life), dreariness (monotony, mundanity), manipulation (advertising) and fragmentation (social isolation) that remain firmly absent - indeed, denied -within the promotional discourse, and are both carefully contained within and foundational to the adaptation itself. Importantly, these utopian qualities and escapist sensibility are hinged around the star casting of Macy, whose presence within Shameless USA not only makes the grittier aspects of the programme 
more likely to be palatable for viewers, but also inflects the grittiness itself - his presence as a star negotiates the seriousness of the lack of wealth and struggle experienced by the characters in the fiction, and his particular acting choices do not inscribe his Frank with the dark, Othered energy that Threlfall cultivates. An unknown performer in the role, especially one with an approach to acting closer to Threlfall's than to Macy's, would have resulted in a rather different Shameless USA, but such a version is highly unlikely to have got commissioned, even for premium cable television.

\section{Conclusion}

Through this article's endeavour to follow a more holistic approach as advocated by Keinonen (2016), the complexity of the push-pull dynamics of fiction format adaptation has forcefully emerged. In the case of Shameless USA, this complexity has been accentuated by the transitional moment marked by the much-anticipated move into original programming by streaming services. This competition has underscored the need for textual identity and to manage discourses of reception for fiction format adaptations, which star casting can help to achieve.

With Threlfall as its Frank, Shameless UK conforms to conventional assumptions about British television drama: connected to the social realist drama tradition, it cast a lead performer who, whilst highly acclaimed among his professional peers, was far from a household name, and whose character's particular construction was permissible within the textual sensibility of the programme. At the same time, Shameless $U K$ also problematises these assumptions by keeping its politics of representation carefully contained. Meanwhile, with its cast headed by Macy, Shameless USA problematises conventional assumptions about US television drama, moving beyond homogenised views of American culture. It simultaneously demonstrates the limits within which such a move can take place (even on premium cable), by keeping its focus firmly on the level of not the structural but the individual; the latter here hinged around a star performer whose presence negotiates notions of ordinariness and extraordinariness and inflects his Frank Gallagher and therefore the overall politics of representation of the adaptation in particular ways.

The complex push-pull quality at stake within each version underscores that there is nothing clear-cut, inevitable or obvious about transatlantic fiction format adaptation. Carlen Lavigne and Heather Marcovitch (2011, xii) rightly point to the absence of certainty when it comes to success and failure, and the presence of star casting in two successful adaptations in recent years, Shameless USA and Netflix's House of Cards, is certainly noteworthy and unsurprising. It points to the importance of casting as one of the textually generative practices (Hogg 2013,127) that are meaningful in the fiction format adaptation process, helping to open up contested cultural space. Whilst to some he may be miscast in the role of Frank Gallagher, Macy's presence in Shameless USA certainly represents a canny industrial strategy, helping to raise the production profile, bestow textual identity, and manage discourses of reception (especially likely Anglophiliac criticism) as well as the text's politics of representation. Such star casting also helps to sufficiently localise the adaptation whilst simultaneously aiming at the international market too, thereby combining local and global perspectives. This is a significant strategy for UK-to-USA adaptations, given that, as Alexandra Beeden and Joost de Bruin have argued, 'the success of an 
adaptation may be linked to its ability to reflect and interpret its new context' (2010, 5). Only, in the case of US television, that new context comprises not solely the national level, with industrial ambitions also regularly marked by an international dimension; and here, the use of star actors as brands themselves can be very useful for such global aspirations.

Hogg has argued in relation to Life on Mars and its short-lived US adaptation (which featured Harvey Keitel in the role of Gene Hunt) that 'in the context of international distribution, this translation partners and complements, rather than erases and supplants, its explicit antecedent, enhancing the potential industry marketability and audience appeal/readability of the overall brand at a global level.' $(2013,123)$ It seems to me that the critical and commercial success of the US versions of Shameless and House of Cards calls for a subtle but significant inflection to this argument: certainly, the William H. Macy and Kevin Spacey versions partner and complement their antecedents. However, they also have at least the potential to erase and supplant, certainly within the viewing public's cultural imagination. In this way, working against conceptions of translation as lack, successful star casting urges us to understand, in Linda Hutcheon's words, adaptation as 'a derivation that is not derivative - a work that is second without being secondary. It is its own palimpsestic thing.' $(2012,9)$ Here, the palimpsest, whilst bearing out the traces of its earlier form, is strongly marked and indeed determined in its meaning by its new shape and the choices that have been made for it, thus engaging in a dialogue with its predecessor from a position of notable textual identity. Through nuanced engagement with the latter, future scholarship on adaptations of both fiction and factually-based formats stands to be enriched.

(10,024 words including endnotes but not including references) 


\section{References}

Abrams, Natalie. 2015. 'Showtime renews 'Shameless,' sets premieres for 'Nurse Jackie,' 'Penny Dreadful' and 'Happyish.' Entertainment Weekly, January 12. http://www.ew.com/article/2015/01/12/shameless-renewed-jackie-penny-happyishpremiere-date

Anderson, J. P. 2015. 'Why William H. Macy Loves Playing Frank Gallagher in Shameless.' Michigan Avenue, January 31.

http://michiganavemag.com/why-william-h-macy-loves-playing-frank-gallagher-in$\underline{\text { shameless }}$

Baker, Stephen. 2009. 'Shameless and the Question of England: Genre, Class and Nation.' Journal of British Cinema and Television 6 (3): 452-467. doi: 10.3366/E1743452109001137.

Barlaam, Sylvia. 2011. "TThere's nowt as Queer as Folk": British and American Televisual Approaches to the Politics of Homosexuality.' In American Remakes of British Television: Transformations and Mistranslations, edited by Carlen Lavigne and Heather Marcovitch, 117-142. Lanham: Lexington Books.

Beeden, Alexandra and Joost de Bruin. 2010. 'The Office: Articulations of National Identity in Television Format Adaptation.' Television \& New Media 11 (1): 3-19. doi: $10.1177 / 1527476409338197$.

Butler, Jeremy G. 1991. 'Introduction to Stars as Cinematic Phenomenon.' In Star Texts: Image and Performance in Film and Television, edited by Jeremy G. Butler, 300-302. Detroit: Wayne State University Press.

Chalaby, Jean K. 2010. 'The rise of Britain's super-indies: Policy-making in the age of the global media market.' The International Communication Gazette 72 (8): 675693. doi: 10.1177/1748048510380800.

Chalaby, Jean K. 2016. 'Drama without Drama: The Late Rise of Scripted TV Formats.' Television \& New Media 17 (1): 3-20. doi: 10.1177/1527476414561089.

Chambers, Deborah. 2001. Representing the Family. London: Sage.

Click, Melissa and Brandon Miller. 2013. 'Is Orange the New Television?' Antenna, October 22. http://blog.commarts.wisc.edu/2013/10/22/is-orange-the-new-television/

Cooke, Lez. 2015. British Television Drama: A History. Second edition. London: BFI.

Creeber, Glen. 2009. “'The truth is out there! Not!': Shameless and the moral structures of contemporary social realism.' New Review of Film and Television Studies 7 (4): 421-439. doi: 10.1080/17400300903306995.

Dalton, Stephen. 2007. 'Mr Suburbia exposes America's dirty secret.' The Times, July 5: 17 . 
Duerden, Nick. 2005. 'To be frank.' The Independent on Sunday, April 17: 14.

Dyer, Richard. 1992. Only Entertainment. London: Routledge.

Dyer, Richard. 1998. Stars. 2nd ed. London: BFI.

Elkin, Susan. 2004. 'Art of the shape-shifter.' The Stage, May 13: 23.

Ellis, John. 1982. Visible Fictions: Cinema, Television, Video. New York: Routledge.

Flax, Jane. 1982. 'The Family in Contemporary Feminist Thought: A Critical

Review.' In The Family in Political Thought, edited by Jean Bethke Elstain, 232-239.

Brighton: Harvester Press.

Geary, Tim. 2007. 'My job is to tell the truth.' Daily Telegraph, June 30: 7.

Griffin, Jeffrey. 2008. 'The Americanization of The Office: A Comparison of the Offbeat NBC Sitcom and Its British Predecessor.' Journal of Popular Film and Television 35 (4): 154-163. doi: 10.3200/JPFT.35.4.154-163.

Halterman, Jim. 2012. 'Interview: "Shameless" Executive producer John Wells.' The Futon Critic, March 9.

http://www.thefutoncritic.com/interviews/2012/03/09/interview-shameless-executiveproducer-john-wells-113210/20120309_shameless/\#8XPExFMSvA2sd8eH.99

'HBO preps US Shameless remake.' Television Business International, December 2008/January 2009: 8.

Hibberd, James. 2011. 'CCalifornication,' 'Shameless,' 'Episodes' are in.'

Entertainment Weekly, January 10.

http://www.ew.com/article/2011/01/10/californication-shameless-episodes-ratings

Hill, Annette. 2016. 'Push-Pull Dynamics: Producer and Audience Practices for Television Drama Format The Bridge.' Television \& New Media 17 (8): 754-768. doi: $10.1177 / 1527476416658131$.

Hogg, Christopher. 2013. 'Cracking the USA? Interpreting UK to US TV drama translations.' New Review of Film and Television Studies 11 (2): 111-132. doi: 10.1080/17400309.2012.708266.

Holliday, Christopher. 2015. 'The Accented American: The New Voices of British Stardom on US Television.' Journal of British Cinema and Television 12 (1): 63-82. doi: 10.3366/jbctv.2015.0243.

Hutcheon, Linda. 2012. A Theory of Adaptation. 2nd ed. New York: Routledge.

Jeffries, Stuart. 2005. 'Why I write.' The Guardian, February 7: 6. 
Jenner, Mareike. 2016. 'Is this TVIV? On Netflix, TVIII and binge-watching.' New Media \& Society 18 (2): 257-273. doi: 10.1177/1461444814541523.

Jermyn, Deborah. 2006. 'Bringing out the star in you?: SJP, Carrie Bradshaw and the evolution of television stardom.' In Framing Celebrity: New Directions in Celebrity Culture, edited by Su Holmes and Sean Redmond, 96-117. London: Routledge.

Jhally, Sut and Justin Lewis. 1992. Enlightened Racism: The Cosby Show, Audiences, and the Myth of the American Dream. Colorado: Westview Press.

Johnson, Beth. 2013. Paul Abbott. Manchester: Manchester University Press.

Jones, Owen. 2011. Chavs: the demonization of the working class. London: Verso.

Jury, Louise. 2007. 'Frank, in more than one sense.' The Independent, January 6: 38.

Keinonen, Heidi. 2016. 'Television format as cultural negotiation: Studying format appropriation through a synthesizing approach.' View: Journal of European Television History and Culture 5 (9): 1-12. doi: 10.18146/2213-0969.2016.jethc103.

Knox, Simone. 2018 (in press). 'Exploring the casting of British and Irish actors in contemporary US film and television.' In Exploring television acting, edited by Tom Cantrell and Christopher Hogg. London: Bloomsbury.

Knox, Simone and Gary Cassidy. 2018 (in press). 'Game of Thrones: Investigating British Acting.' In Contemporary Transatlantic Television Drama: Industries, Programs and Fans, edited by Matt Hills, Michele Hilmes and Roberta Pearson. Oxford: Oxford University Press.

Lavigne, Carlen and Heather Marcovitch. 2011. 'Introduction.' In American Remakes of British Television: Transformations and Mistranslations, edited by Carlen Lavigne and Heather Marcovitch, ix-xvii. Lanham: Lexington Books.

Luckhurst, Mary and Chloe Veltman, eds. 2001. On Acting: Interviews with Actors. London: Faber.

Macdonald, Marianne. 2004. 'Why the long face?' Sunday Telegraph Magazine, May 30: 17 .

Miller, Jeffrey S. 2000. Something Completely Different: British Television and American Culture. Minneapolis: University of Minnesota Press.

Millington, Bob. 1993. 'Boys from the Blackstuff(Alan Bleasdale).' In British Television Drama in the 1980s, edited by George W. Brandt, 119-139. Cambridge: Cambridge University Press.

Moran, Albert. 2009. New Flows in Global TV. Bristol; Chicago: Intellect.

Nelson, Robin. 2007. State of play: Contemporary "high-end" TV drama. Manchester: Manchester University Press. 
O'Connell, Michael. 2014. 'TV Ratings: 'Shameless' and 'House of Lies' Nab More Highs With Finales.' The Hollywood Reporter, April 7.

http://www.hollywoodreporter.com/live-feed/tv-ratings-shameless-house-lies-694184

Oren, Tasha and Sharon Shahaf, eds. 2012. Global Television Formats:

Understanding Television Across Borders. New York: Routledge.

John Plunkett. 2011. 'Here's to television's special relationship.' The Guardian, 17

January 17: 3 .

Rampton, James. 2009. 'Paul Abbott: My Shameless Life.' The Independent, April 2. http://www.independent.co.uk/news/people/profiles/paul-abbott-my-shameless-life$\underline{\text { 520219.html }}$

Rochlin, Margy. 2011. 'The Family That Frays Together.' The New York Times, January 2: AR.7.

Sepinwall, Alan. 2013. ' House of Cards' Director David Fincher on Making 13 Hours for Netflix.' What's Alan Watching: Inside Television with Alan Sepinwall, January 29.

http://www.hitfix.com/whats-alan-watching/house-of-cards-director-david-fincheron-making-13-hours-for-netflix

Stanley, Alessandra. 2011. 'Sincerest Forms of Flattery for British Shows.' The New York Times, January 7: C.1.

Steemers, Jeanette. 2004. Selling Television: British Television in the Global Marketplace. London: BFI.

Straubhaar, Joseph. 2000. 'Culture, Language and Social Class in the Globalization of Television.' In The New Communications Landscape: Demystifying Media

Globalization, edited by Georgette Wang, Jan Servaes and Anura Goonasekera, 202228. London: Routledge.

Taylor, Ella. 1989. Prime-Time Families: Television Culture in Postwar America. Berkeley: University of California Press.

Weissmann, Elke. 2012. Transnational Television Drama: Special Relations and Mutual Influence between the US and UK. Houndmills: Palgrave Macmillan.

Wylie, Ian. 2010. 'Interview Paul Abbott: 'We've got a really posh audience'.' The Guardian, November 29: 5.

Zoller Seitz, Matt. 2011. “"Shameless”: American TV's problem with class.' Salon, January 8. http://www.salon.com/2011/01/08/shameless_remake/ 


\footnotetext{
${ }^{1}$ As Jeremy G. Butler has argued, 'even though Ellis denies the existence of stars on television, the terms of his analysis [...] may well illuminate the significance of television's celebrities.' (1991, 302).

${ }^{2}$ For example, the video-sharing website Dailymotion contains a montage of excerpts from the first three episodes of both versions that demonstrates their similarities:

http://www.dailymotion.com/video/xgqgbm uk-us-shameless-pilot-comparison shortfilms. ${ }^{3}$ Johnson proceeds to undertake an insightful comparative analysis of the Shameless opening credits.

${ }^{4}$ Interestingly, given the close links between the family and the nation (Chambers 2001), Shameless USA's marked insistence on the family as, despite its challenges, ultimately surviving and forward-moving, can be read as a (somewhat wishful) metaphor for the larger social order of the contemporary USA.

${ }^{5}$ This star casting represents an interesting contrast to the US creative industry's recent trend of casting relatively unknown British and Irish actors for projects that stand to benefit from the 'productive anonymity' (Holliday 2015, 64) offered by such actors. See Knox 2018 (in press). ${ }^{6}$ With the show on production hiatus at the time of writing, the current focus on the character of Claire Underwood on the Netflix cover photo indicates that Netflix is in the process of reanchoring the programme towards Robin Wright. It remains to be seen in what ways recent developments will impact House of Card's position in industrial contexts and place within cultural memory in the long term.

${ }^{7}$ There are clear links here between my discussion and Hogg's (2013) analysis of the US version of Cracker (ITV 1993-2006), especially the construction of the lead character Fitz (in this case, for network television).
} 